\title{
茶のクロロフィルの分離定量法*
}

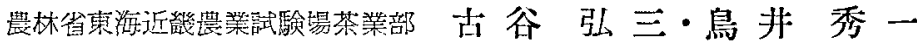

\section{Determination of Chlorophyll in Tea}

\author{
By Kôzô Furuya and Hideichi Torir
}

\section{1.まええがき}

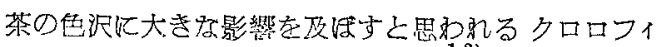
ルの定舅法について砄究を猚めてきたが，その抽性条件， 分離操作，測定方洁について一充の結果を得ることがで

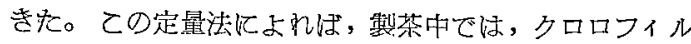
$\boldsymbol{a}$ は加憼の影留に上つて大部分变化してクロロフィル $\boldsymbol{a}$ の形では存在はす，その分解物の一つである phacophorbide $a$ 亡思わ机る物賴となつていることが，初めて明 らかになつた。

クロロフィルの定䈏法は WILLSTÄTTER 以来程々の 万法が案出されているが，近年になつて，波舆 $660 \mathrm{ma}$ 附 近保るクロロフィルの吸収の山を利用し范, A. O. A. C. 公定法抢よび C. L. CoMAR, E. P. ZscheIre 0 分光

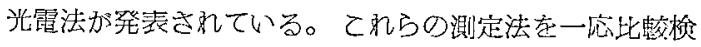
討すべきであるが，基準となるクロロフィルを來分解の

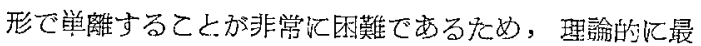

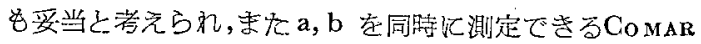
のお法が，茶のクロロフィルを測定する場合，そのまま 伈用できるかどうかを众討した。

\section{2. 実 験 $の$ 部}

\section{1. クロロフィルの抵出}

試料からクロロフィルを抽出する溶剂としては，アル コール・石沾エーテル等種々の有機溶斉が守いられて きているが，アルコールは直接クロロフィルと化合物を 作るし，石油類はワックス等を抽出し孙い利点が数马肪， クロロフィルの完全抽比が困蜼でするなごそれぞれ一長

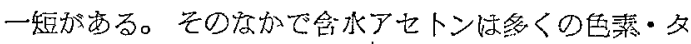
ンニン等年同時に抽出はするが，鼠も察易に，かつ，完 全に抽出するので, 定量の場合に性最も適している。

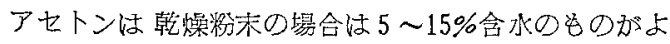
く，5\%以下，または15\%以上になると括出力加減少す

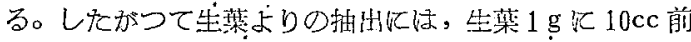
後の脱水アセトンが最も掻出しや专い。

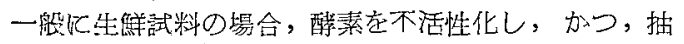
出を客易にするために，蒸熱观理䒚行うが，乙れ後の
クロマトグラフのとしろで述べるように， クロロフィル の分解を伴う。枃えに生葉の場合は脱水アセトン和で海

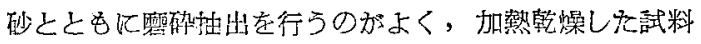
では，どうしても相当量のクロロフィルの牙解在伴うこ と过避讨られな。

\section{2. クロロフィルの分離}

アセトン抽出液そのまま（エーテルに慙溶して漕縮し た活うが容易である）ミクロピペットで 0.01〜0.1cc 程 度を円型滤炠（佳 $11 \mathrm{~cm}$ ) の中央に滴下し，展開剤 $\mathrm{I}$ (石 油エーテル：ベンゼン＝4：1 vol）で展開するを，外側 よりカロチン（ $\beta$ が低とんじ全部と思われる），灰緑色色

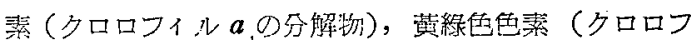
イ心 $b$ 分解物)，キサントフイル類 2 （内則はルテイ ン上思われる肪，外側は不服），クロ䓃フィル $a$ ，クロロ

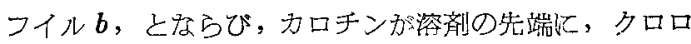
フィル $b$ が原点の周辺火，主の和の同心円を机て分離

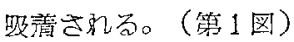

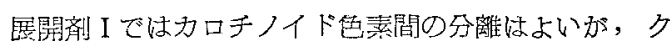
ロロフィル $a, b$ は近接して吸置され，完全に分離抽出 することは囷奞である。それで展開剤川（ペンゼン：四

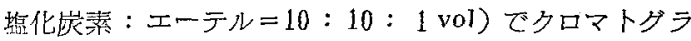

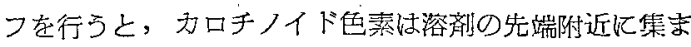
るが,クロロフィル $a, b$ は中間行完全敒分離して吸盖 され（第2図），個々に切り取り，エ一テルで抽出するこ とができる。

ふお，乙の植勒色素のクロマトグラフは吸着クロマト グラフで $R f$ は一定せず，濃度により屡間距離が異なる

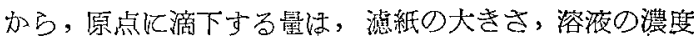
により適当儿調節しなけれけすならない。

\section{3. 定量法の検討}

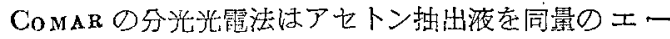
テルと混合し，水を加沈てクロロフィルを江ーテルに転 溶し，エーテル溶液起水で躁り返し洗浔してアセトンを

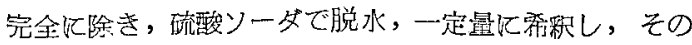

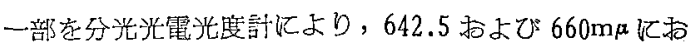
将る吸光辰学 $\log \mathrm{I}_{0} / \mathrm{I}$ 值で測定し, 次の式よりクロロフ ^ル $a, b$ 和上び $a+b$ を算出するカ法である。

* 茶業技術研究 No.16，32３6（1957）より転載 
$a(\mathrm{mg} / \mathrm{L})=9.93 \log \mathrm{I}_{0} / \mathrm{I}(660)$

$-0.777 \log I_{0} / I(642.5)$

$b(\|)=17.6 \log I_{0} / I(642.5)$

$-2.81 \log I_{0} / I(660)$

$a+b(/ /)=7.12 \log \mathrm{I}_{0} / \mathrm{I}(660)$

$+16.8 \log \mathrm{I}_{0} / \mathrm{I}(642.5)$

$\log \mathrm{I}_{0} / \mathrm{I}(660) ，(642.5)$ はそれぞれ

$660 \mathrm{~m} \mu, 642.5 \mathrm{~m} \mu$ 的ける吸光度。

上の式は CoMAR らが办ずから精㹕 したクロロフィルについて, 数力所の波 長の吸光係数救めて算き出したもので ある。

クロマトグラフで分離し, エーテルで 抽出したものについては，上の式により 且ちにその量は算出できるが，アセトン 抽出液をエーテルに転溶したものを滇接 分光光度計にかる場合は, 上式の二つ の波長附近に大き双收収を持物想の有 無を検討しなけ託ばならない。この点に ついて謂へた結果, 繁菜中にはこの附近

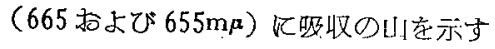
物啠方相当量存在するととが判明した。

すねわち，第 1 表に示すように，生葉

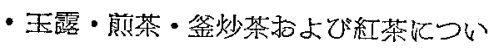
て Comar の方法で定量したものと， クロマトグラフによつて $\boldsymbol{a}, \boldsymbol{b}$ を分離し エーテルで抽出した後，同じ数式で計算 したものと在比較すると, 生葉・玉潞に

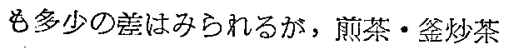
・細茶では䒠袮にはクロロフィル $\boldsymbol{a}$ は己 くかず加し，または全く含ま机ていな Wのに, COMAR の定量法そのままの場 合は相当量が存在与る值を示している。
第 1 図 製茶アセトン抽出液のクロマトグラム

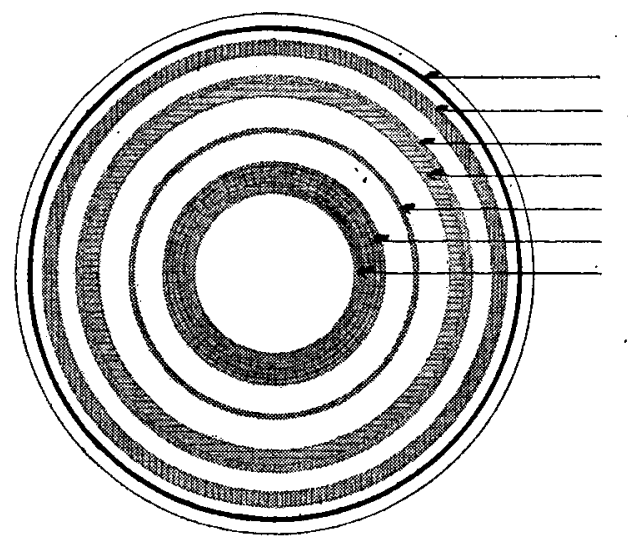

カロチン

$a^{\prime}$

キサントフィル

ルテイン

クロロフィル $a$

クロロフィル $b$

展開刋 I

石油エーテル:ヘンゼン

$=4: 1$

管 2 図制茶アセトトン抽出液のクロマトグラム

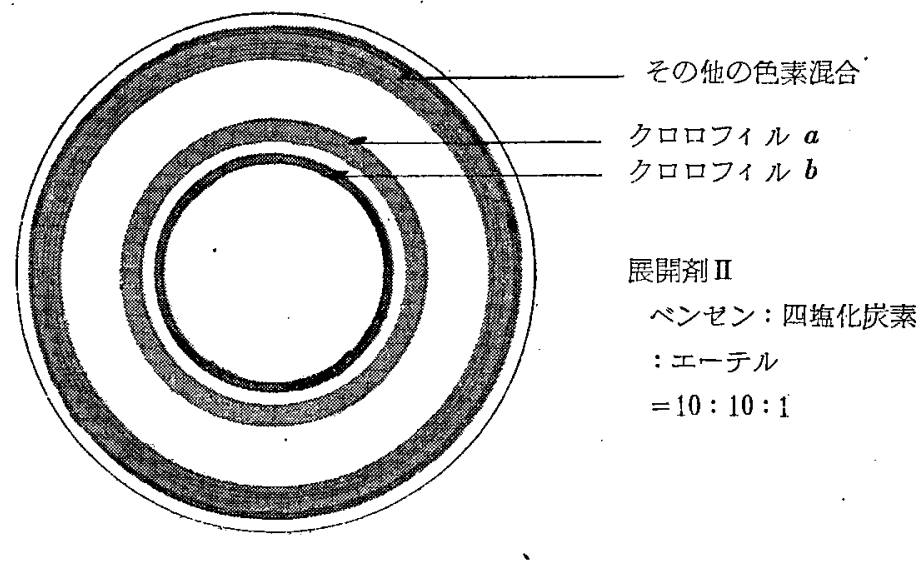

第 1 表 各種製茶中のクロロフィル含有量 $(\mathrm{mg} \%)$

\begin{tabular}{|c|c|c|c|c|c|c|c|c|c|c|}
\hline $\begin{array}{l}\text { クロロ } \\
\text { フィル }\end{array}$ & 生 & 葉 & 玉 & 露 & 釜 & 茶 & 紊 & 茶 & 䋊 & 茶 \\
\hline$a$ & 570 & 168 & 536 & 150 & 472 & 47 & 304 & 44 & 280 & - \\
\hline$b$ & 319 & 172 & 205 & 193 & 139 & 67 & 123 & 67 & 32 & - \\
\hline$a^{\prime}$ & & 369 & & 426 & & 477 & & 484 & . & 555 \\
\hline
\end{tabular}

请考：細字はアセトン抽出液そのまま, 太字はクロマトグラフで分離啳 COMAR の式に说つて算出した

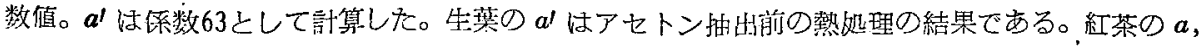
bはクロマトグラムにて認められなかつたので切り取り抽出しなかつた。

してがつて制茶中凡は，ComaR の方法ではクロロフ イル $\boldsymbol{a}$ として定量される他の物臀が含まれているととが 考えられる。そこで, 制茶のアセトン抽出液をエーテル

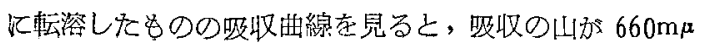

より $5 \mathrm{~m} \mu$ だけ長波長の側にずれていることがわかつた。 また，展開剤で展開したクロマトグラムの先端に集ま

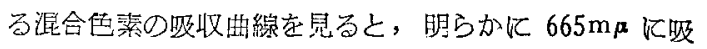
収の比老現かしている。更に展開 I でこれら混合色素 
を分離して，個々の色素の吸収曲線を見ると，カロチン とキサントフィルの闍に展開されている灰綠色 ( $a^{\prime}$ と仮 称）と黃綠色 ( $\boldsymbol{b}^{\prime}$ と仮称) の二つの巴素市，乙の附近に 叹収の!山を現わし， $a^{\prime}$ はクロロフィル $a$ と低とんど同型 の曲線を画き，407.5 和よび $665 \mathrm{~m} \mu$ (クロロフィル $a$ は

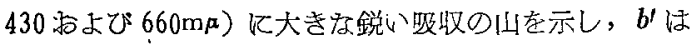
433.5 おัよび $655 \mathrm{~m} \boldsymbol{\mu}$ K吸收の山を現わし, クロロフィル $b$ (460 拘よび $642.5 \mathrm{mp}$ ) と同型の吸収曲線を画く（第3， 4 図)。

第 3 図 クロロフィル $a$ および $a^{\prime}$ の エーテル溶液の吸収スペクトル

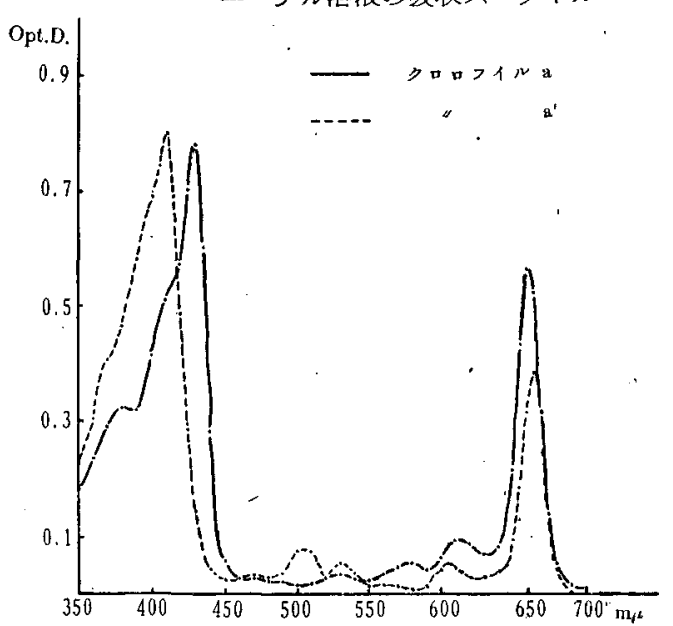

第 4 図 クロロフィル $b$ 於よず $b^{\prime}$ の エーテル溶腹の昅収スペクトル

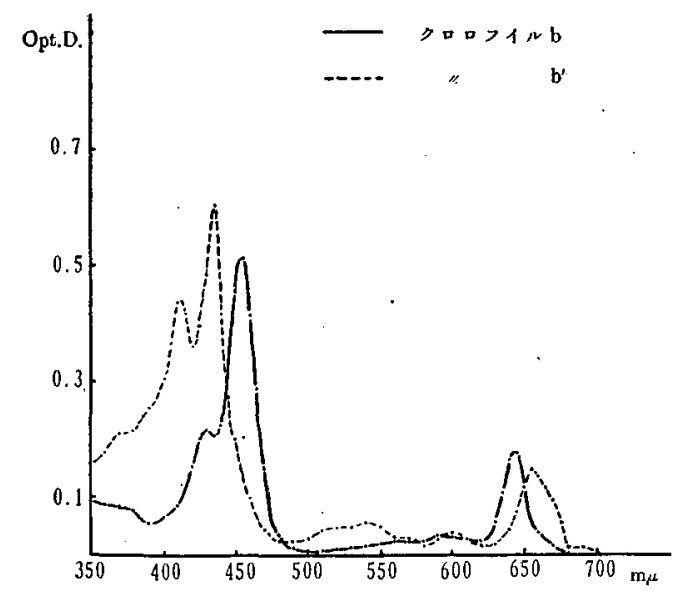

その他の刃ロチンおよびキサントフィル類は， $550 \mathrm{~m} \mu$ より長设長部に忙大な吸收の山を示さないから（第 5 図), $a^{\prime}$ と $b^{\prime}$ 二つの出素がクロロフィル $a$ として定量 されており；乙れらはその樶収曲線の型からみて，クロ ロワィルの分解物瞔のように考えられる。

この二つの物質の影響の程度をるる，

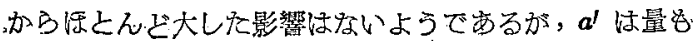

第 5 図 カロチノイド蒵のエーテル 溶液の吸収スペクトル・

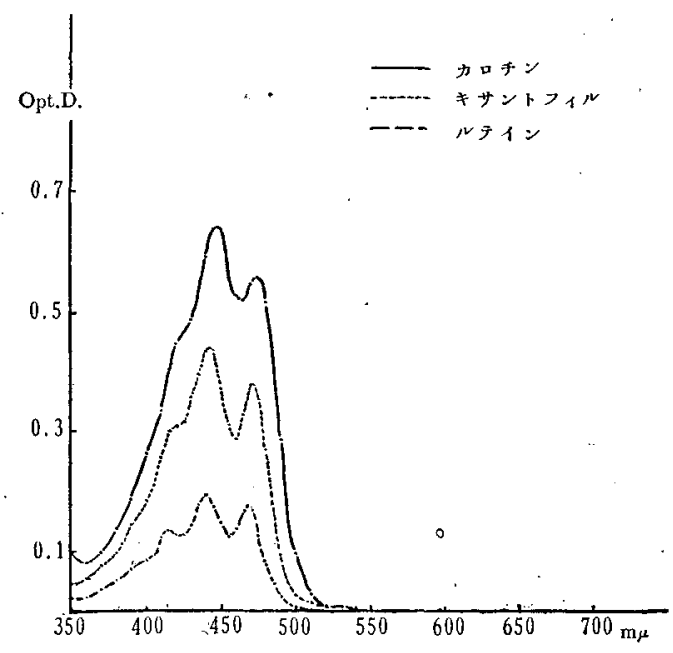

多く $660 \mathrm{~m} / 2$ で相当の吸取安現わしている。

また，乙の $a^{\prime}, b^{\prime}$ 色素は荼葉だけでねく，多くの線葉

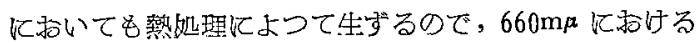
吸光度を利用した定毁法は，試料分熱処理されているも

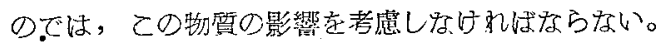

$a^{\prime}$ 色素の紹奶罝の算出は，現在クロマトグラフによつ

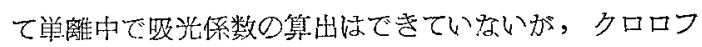

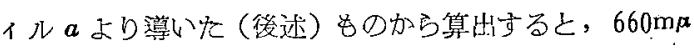
で 55, 665maで630值を示し，クロロフィルaは660ma で $102 ， 665 \mathrm{~m} \mu$ で 61.2 となるから，乙れから次の式で $a ，$ $a^{\prime}$ 算出できる。

$$
\begin{aligned}
& a=20.6 \log _{10} \mathrm{I}_{0} / \mathrm{I}(660)-17.1 \log _{10} \mathrm{I}_{0} / \mathrm{I}(665) \\
& a^{\prime}=33.3 \log _{10} \mathrm{I}_{0} / \mathrm{I}(665)-20.0 \log _{10} \mathrm{I}_{0} / \mathrm{I}(660)
\end{aligned}
$$

ただし上式の吸光粍数低いまだ実験の繰り返しが少い

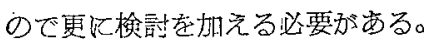

4. $a^{\prime}$ および. $b^{\prime}$ の同定

こ肺ら $\boldsymbol{a}^{\prime}, \boldsymbol{b}^{\prime}$ は生葉になく，製茶に多く存在して古 り，また釜炒䒩製造行程の各段階についての消長加らみ て (後述)，クロロフィル $a ， \boldsymbol{b}$ の分解物のように考えら れるので，展開剂川で分㒕したクロロフィル $\boldsymbol{a}, \boldsymbol{b}$ 在酸一 ( $\boldsymbol{a}$ の場合堷酸 1:3，bの場合 1:1), あるいはアルカ リ（メタノール・カリ溶液）で分解し，アルカリ迈理液 は水溶性のため，画び酸処理を行つてエーテルに転溶し たもの(前者は phaeophorbide $a, b$ で, 後者はchlorin $\mathrm{e}$, rhodin $\mathrm{g}$ である), と比䧶すると, $a^{\prime}$ と phaeophorbide $\boldsymbol{a}, \boldsymbol{b}^{\prime}$ と phaeophorbide $\boldsymbol{b}$ の吸収曲線は全く同型と

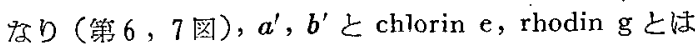

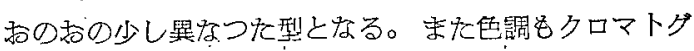
ラフも同様に phaeophorbideと一致するので, chlorin e まよび rhodin g ではないが，加熱处理だけで， Mg お よび phytol 在つた phaeophorbide まで分解される ものか，またそれ以、分解の進んだものが含まれていな 
いかなど種々の疑閆はするが，乙れらの点は今後の研究 によつて明らかにするつもりである。

現在までに判明した点は以上のぼに， $\mathrm{Mg}$ を含んで いないとと，クロロフィルと巽なつて，二硫化㞸莱に溶 解するととなどである。

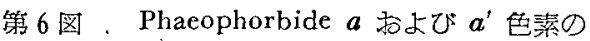
エーテル容液の收収スペクトル

Opt.D.

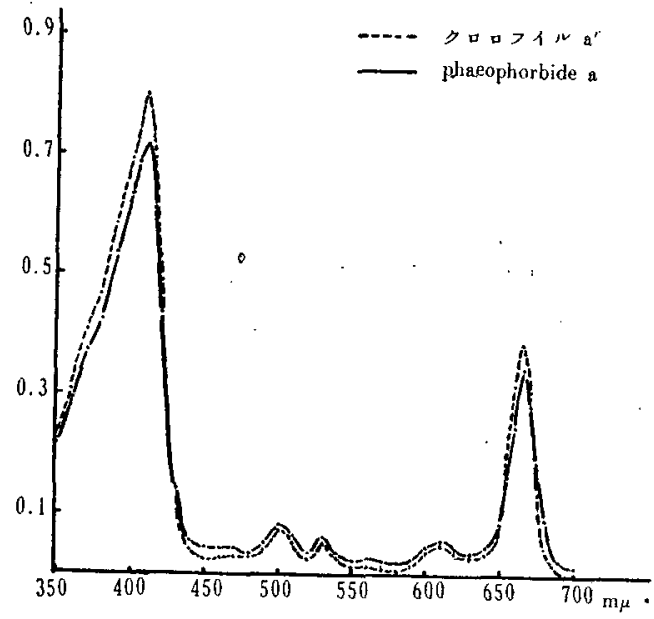

第 7 图 Phaeophorbide $\boldsymbol{b}$ 扰よび $\boldsymbol{b}^{\prime}$ 色素の エーテル溶液の樶収スペクトル

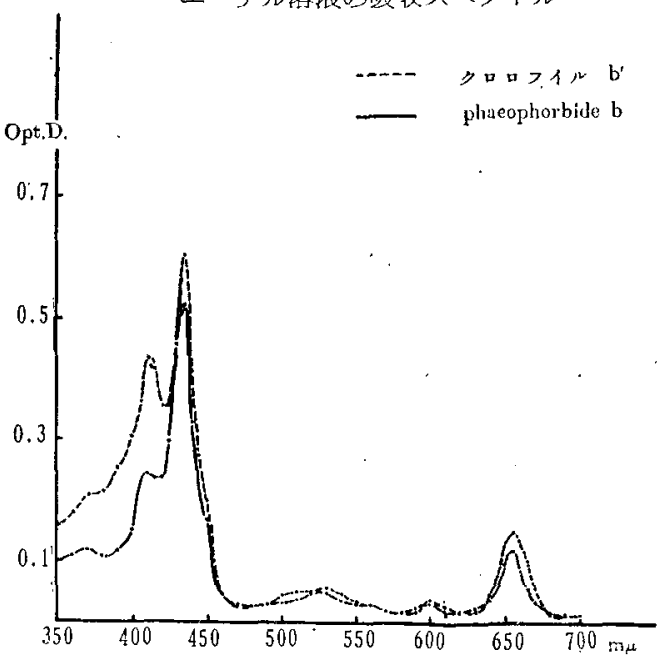

5.発茶工程中のクロロフィルの消長

㹕茶中最も高温処理を受ける鉒炒茶の製造工程中の》 ロロフィルの変化を調へてみると, 第 2 素に示すように， $\boldsymbol{a}$ 訬炒の段階ですでに大部分が分解され，百に工程が 進むにつれてますます減少して，製昆ではクロマトグラ ムに現わ䶻くなが，bは整品まで相当量残つている。

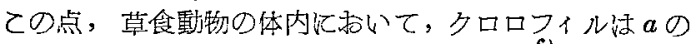
压うが $b$ より速や加分解するという報告上同し傾向 を示している。末た工程が進むに往つて， $a$ の減少とは 比例しないが， $a^{\prime}$ は堌加している。
なお，ての表に斿いて生葉に $a^{\prime}$ が相当量含有されてい

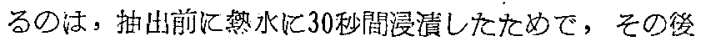

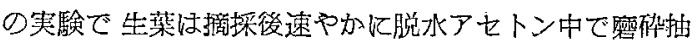

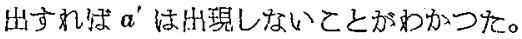

第 2 素 釜炒茶製毕工程中のクロロフィルの消梫

(mg\%)

\begin{tabular}{|c|c|c|c|c|c|c|}
\hline $\begin{array}{l}\text { クロロ } \\
\text { フィル }\end{array}$ & 生 䇥 & 炒 葉 & $\begin{array}{l}\text { 第 } 1 \\
\text { 水乾箖 }\end{array}$ & $\begin{array}{l}\text { 第 } 2 \\
\text { 水轨葉 }\end{array}$ & 製 & 品 \\
\hline$a$ & 168 & 42 & 38 & 37 & & - \\
\hline$b$ & 172 & 95 & 114 & 123 & & 80 \\
\hline$a^{\prime}$ & 369 & 530 & 516 & 603 & & 572 \\
\hline
\end{tabular}

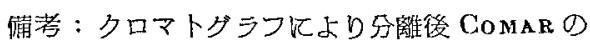
式により計算したもの。 $a^{\prime}$ は伱数63亡し て計算した。生葉の $\boldsymbol{a}^{\prime}$ はアセトン抽出前 の熱如理の縝果である。製品のaはタロ マトグラムで羿められなかつたので測定 し存かつた。

\section{3. 要 約}

菒のクロロプイル定鼠法について鿬究し，抽出，分離 測定条件を決定した。

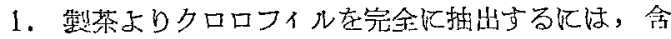
水率10\%前後のアセトンが最もよく，生葉の場合江第 1 回目の抽出脱水アセトンを用い各恬うがよい。ただし 抽出前の胡熱処理は クロロフィルの分解を伴うから避け なけれ彷ならない。またクロロフィルを保存するには，

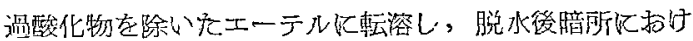
涩 1 华くらい変化しない。

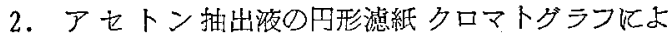
り，クロロフィル $\boldsymbol{a}, \boldsymbol{b}$, カロチノイド韭猄, およびクロ ロフィルの分解物之思われる2種の色素が 完全份分離さ

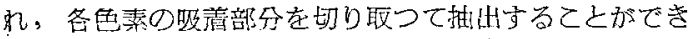
b。

3. 波長 $66 \mathrm{fm} \mu$ の吸光度在利用与るクロロフィル定量 法では，カロチノイド色䨒は影檘を及ぼさないが，クロ ロフィルの行解物々思狆る色素が大きく影響する。製 茶中にはこの出素が非常に多く含まれ，上の定最法をそ のまま適用すると，生葉のクロロフィルの半分近くが溆 茶中に残つている計算に名るが，実際には $b$ が30\%程度 残つているのみで， $a$ は大部分分解されている。

4. この二つの鼠はクロロフィル $a, b$ より導い phaeophorbide $a, b$ 上吸收曲線が一致している。

5. 王簬の中にはクロロフィル $a, b$ とむに相当量末 分解で残つているが, 煎茶・釜炒茶にはクロロフィルa

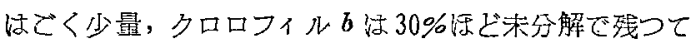
，いるに导ない。紅茶では $a ， b$ とも火完全飞予解されて 
いる。

これらの結果から，玉露・碾茶の解緑绝は末分解のク ロロフィルに基因し，煎茶・鉒炒茶等の黑味を带びた色 沢は，乙の分解物と思われる灰緑焦の色菜化よるものと 洘えられる。

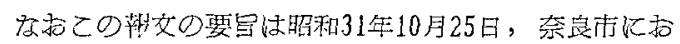
ける日本茶業技術協会研究発表会で欂演した。

\section{4. 文献}

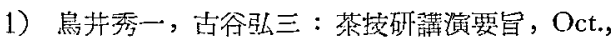
1952, p. 10 .

2）古谷弘三：茶技研䛔演要昌，Oct., 1954， p.22.

3) Method of Analysis of A.O.A.C., 7 ed., $111 \sim 12$ (1950).

4) Comar, C. L., F.P. Zscheite: Plant Physiol.' 17, 198 209 (1942).

5)

$16,651 \sim 53(1941)$.

6）服部静夫：植物色素の矿究成果，p.835（i941）。

\section{Summary}

- For determining chlor phyll- $a$ and $\cdot b$ in made tea or tea leaf, the follow:ng experiments were performed.

1. To extract chlorophyll completely from made tea, three or more successive extractions with acetone containing $10 \%$ water were necessary, but when the sample was fresh leaf, undild. acetone should be used at the first time and never had to give heating before extraction, unless otherwise the decomposition of chlorophyll could not be avoided.

2. By circular paper chromatography of the acetone extract with the mixed solvents of petroleum ether : benzene $(4: 1)$ or benzene : carbon tetrachloride : ether $(10: 10: 1)$, chlorophyll- $a,-b$, carotenoids and two unidentified pigments were separated clearly, and these pigments could be eluted by ether.

3 . The ether solution of chlorophyll was estimated by measuring the optical density with a spectral monochromate near $660 \mathrm{~m}$; . The measurement was greatly interfered by the unidentified pigments but not by the carotenoids.

4. The two unidentified pigments which were contained in an appreciable quantity in made tea seemed to be the degradation products of chlorophyll- $a$, and $-b$ whose absorption spectra agreed well with those of phaeophorbide- $a$, and $-b$ and the color was greyish green and yellowish green respectively.

5. In Gyokuro, some amounts of chlorophyll- $a$ and $-b$ were contained, but in Sench $a$ and pan-parched tea a trace of chlorophyll-a and a small amount of chlorophyll-b. were merely detected and in black tea both chlorophyll-a and $-b$ completely disappeared.

It was presumed that the fresh green color of Gyokuro and Tencha was due to the undecomposed chlorophyll but' the dark green color of Sencha and pan-parched tea was characterized by the phaeophorbide-like pigments.

(Feb. 11, 1957) 